\title{
PENGARUH LATIHAN FISIK DENGAN FLEXIBILITY EXERCISES TERHADAP KEMAMPUAN ACTIVITY DAILY LIVING'S (ADL's) PASIEN KANKER DI MURNI TEGUH MEMORIAL HOSPITAL
}

\author{
${ }^{1}$ Yusrial Tarihoran, ${ }^{2}$ Seriga Banjarnahor \\ 1,2Dosen Prodi S1 Keperawatan, STIKes Murni Teguh, Jalan Jawa No. 2 Gang Buntu Medan \\ E-mail : ${ }^{1}$ yusrialtarihoran@gmail.com, ${ }^{2}$ serigabanjarnahor@yahoo.com
}

\begin{abstract}
ABSTRAK
Kanker merupakan penyakit dengan pertumbuhan dan penyebaran sel abnormal oleh berbagai faktor seperti penggunaan tembakau, genetik, hormon, dan gangguan kekebalan tubuh sehingga sering mengalami keluhan fisik seperti kelemahan akibat kurangnya energi didalam tubuh dan berdampak terhadap kemampuan melakukan Activity Daily Living's (ADL's). Penelitian ini bertujuan untuk menganalisis pengaruh latihan fisik dengan flexibility exercises terhadap kemampuan Activity Daily living's (ADL's)pasien kanker di Murni Teguh Memorial Hospital dengan kriteria sampel yaitu pasien yang menjalani kemoterapi, tidak memiliki luka akibat kanker, tidak mengalami anemia, tidak mengalami fraktur, berjenis kelamin perempuan kooperatif dan memiliki rekomendasi dari dokter untuk melakukan latihan fisik dengan flexibility exercises. Metode penelitian ini menggunakan rancangan one group pre-post test designe. Latihan fisik dengan flexibility exercises dilakukan minimal 30 menit setiap kali melakukan latihan dan dilakukan 3 kali seminggu selama 30 kali pertemuan dengan jumlah sampel sebanyak 30 orang dengan teknik accidental sampling. Luaran wajib penelitian ini berupa publikasi ilmiah jurnal nasional tidak terakreditasi dan luaran tambahan berupa keynot speaker/invited dalam temu ilmiah lokal dan nasional serta pembuatan bahan ajar di bidang pelayanan asuhan keperawatan pasien kanker dan juga paliatif care di bidang onkologi (kanker). Adapun tujuan dari Tingkat Kesiapterapan Teknologi (TKT) penelitian ini adalah berbagai produk alat kesehatan, berupa perumusan topik-topik penelitian, menyusun hipotesis, merencanakan rancangan experimen untuk menemukan solusi permasalahan, mengidentifikasi potensi dan peluang target terapi, pembuktian terhadap kebenaran konsep (proof-of-concept), penyusunan prosedur dan metode yang digunakan dalam studi klinis dan publikasi pembuktian kebenaran konsep.
\end{abstract}

Kata Kunci : Flexibility exercises, Activity Daily Living's (ADL's).

\section{ABSTRACT}

Cancer is a disease with the growth and spread of abnormal cells by various factors such as tobacco use, genetic, hormones, and immune disorders that often experience physical complaints such as weakness due to lack of energy in the body and impact on the ability to do Activity Daily Living's (ADL's). This study aims to analyze the effect of physical exercise with flexibility exercises on the ability of Activity Daily living's (ADL's) cancer patients at Murni Teguh Memorial Hospital with sample criteria: patients who undergo chemotherapy, have no cancerous injuries, no anemia, no fracture, type female genitals are cooperative and have recommendations from doctors to do physical exercises with flexibility exercises. This research method uses one group pre-post test design design. Physical exercises with flexibility exercises are performed at least 30 minutes each time doing the exercises and carried out 3 times a week for 30 meetings with a total sample of 30 people with accidental sampling technique. The mandatory outcomes of this study are scientific publications in national journals that are not accredited and additional outcomes in the form of keynot speakers / invited in local and national scientific meetings and the making of teaching materials in the field of nursing care services for cancer patients and also palliative care in the field of oncology (cancer). The purpose of this Technology Readiness Level (TKT) of this research is a variety of medical equipment products, in the form of research topics, formulating hypotheses, planning experimental designs to find solutions to problems, identifying potential and opportunities for therapeutic targets, proving the truth of the concept (proof-of-concept), preparation of procedures and methods used in clinical studies and publication of proof of concept truth.

Keywords :Flexibility exercises,Activity Daily Living's (ADL's). 


\section{PENDAHULUAN}

Kanker merupakan penyakit yang ditandai dengan pertumubuhan dan penyebaran sel abnormal yang disebabkan oleh berbagai faktor seperti penggunaan tembakau, genetik, hormon dan gangguan kekebalan tubuh dan dapat mengakibatkan kematian. Menurut data GLOBOCAN (2012) terdapat 14.1 juta kasus kanker baru dan 8.2 juta diantaranya mengalami kematian. Pasien kanker sering mengalami keluhan fisik seperti kelemahan akibat kurangnya energi didalam tubuh sehingga mengakibatkan istirahat yang cukup lama dan mengakibatkan hilangnya fungsi tubuh, kelemahan dan kehilangan gerak otot yang berdampak terhadap gangguan kemampuan melakukan Activity Daily Living's (ADL's, ) (Don et, al, 2017).

Kemampuan Activity Daily Living's ( $A D L$ 's) individu selama satu minggu melakukan aktivitas fisik jalan cepat, bersepeda, berkebun, berlari, aerobik, pekerjaan halaman yang mengakibatkan peningkatan bebean kerja jantung dan pernapasan menunjukkan perbedaan yang signifikan yaitu 1) rata-rata waktu >150 menit/minggu sebanyak $26.7 \%$ individu yang mengalami penyakit kanker dan 23\% individu yang tidak mengalami penyakit kanker 2) ratarata waktu $>150$ menit/minggu yaitu $56.1 \%$ untuk individu yang mengalami penyakit kanker dan $65.7 \%$ individu yang tidak mengalami penyakit kanker (Zhao et,al, 2012)

Kemampuan Activity Daily Living's ( $A D L$ 's) pasien kanker yaitu mandi 5\% berpakaian 4\%, makan 4\%, kemampuan memimpin 9\%, berjalan 14\% dan toileting 3\% sedangkan kemampuan Actvitiy Daily Living's (ADL's) individu yang tidak mengalami penyakit kanker yaitu makan $12 \%$, berpakaian $7 \%$, kemampuan memipin $4 \%$, berjalan $20 \%$ dan toileting 7\%. (Min et al, 2017). Dari data tersebut dapat diketahui bahwa pasien kanker harus mampu meningkatkan Activity Daily Living's (ADL's), salah satu intervensi yang dapat dilakukan oleh pasien kanker untuk meningkatkan Activity Daily Living's (ADL's) adalah program latihan fisik dengan fleksibility exercises yang dilakukan secara rutin sehingga dapat menjaga flekisbilitas dari peregangan sendi dan otot seluruh tubuh dan sesuai prosedur dengan tujuan mampu melakukan Activity Daily Living's ( $A D L$ 's). Tujuan penelitian ini adalah untuk menganalisis pengaruh latihan fisik dengan Flekisbility Exercises terhadap kemampuan melakukan Activity Daily Living's (ADL's) pasien kanker di Murni Teguh Memorial Hospital.

Pasien kanker memiliki salah satu komplikasi penyakit akibat kemoterapi yaitu kelemahan yang mengakibatkan terganggunya kemampuan melakukan Activity Daily Living's (ADL's). Berdasarkan penelitian Min et al (2017) kemampuan Activity Daily Living's ( $A D L$ 's) pasien kanker yaitu mandi $5 \%$, berpakaian $4 \%$, makan $4 \%$, kemampuan memimpin $9 \%$, berjalan $14 \%$ dan toileting $3 \%$. Salah satu intervensi yang dapat dilakukan oleh pasien kanker untuk tetap dapat mempertahankan keseimbangan energi didalam tubuh dan membantu meningkatkan kemampuan melakukan Activity Daily Living's (ADL's) adalah program latihan fisik dengan fleksibility exercises.

Kemampuan Activity Daily Living's ( $A D L$ 's) pasien kanker mengalami penurunan yaitu mandi $5 \%$, berpakaian $4 \%$, makan $4 \%$, kemampuan memimpin $9 \%$, berjalan $14 \%$ dan toileting 3\%. Pasien kanker mengalami keluhan melakukan Activity Daily Living's $(A D L ' s)$ di rumah yaitu sebanyak $65 \%$ responden mengatakan mengalami gangguan aktivitas perawatan diri, $25 \%$ mengalami gangguan rekreasi dan $19 \%$ mengalami gangguan terhadap pekerjaan yang menghasilkan keuangan, (Jacobsen et,al 2012). Salah satu intervensi yang dapat dilakukan pada pasien kanker untuk menjaga kekuatan otot serta meregangkan otot-otot yang kaku akibat komplikasi penyakit kanker untuk mampu mempertahankan kemampuan melakakukan Activity Daily Living's ( $A D L$ 's), (Cancer Council, 2016).

Latihan fisik merupakan salah satu intervensi rehabilitasi dengan melakukan pergerakan otot-otot tubuh untuk meningkatkan kesehatan tubuh, mempertahankan kesehatan jasmani, membantu pasien beradaptasi dengan penyakit kanker dan pengobatannya dengan tujuan dapat mengembalikan pola hidup yang normal, (Powers S. K et al, 2008). 
Latihan fisik yang dapat dilakukan pasien kanker adalah latihan fisik minimal yaitu latihan fisik yang menghasilkan denyut jantung antara 50-60\% dari denyut jantung maksimal seperti latihan fisik dengan fleksibility exercises. Intensitas latihan yang sesuai dengan anjuran terapi adalah dengan menggunakan intensitas latihan ringan yaitu latihan fisik yang dilakukan minimal 30 menit setiap kali latihan dan dilkaukan 3 kali seminggu selama 30 kali pertemuan (Cancer Council, 2016).

Fleksibility exercises merupakan latihan peregangan atau rentang gerak untuk memperpanjang serta menjaga fleksibilitas sendi dan otot. Latihan pergerakan otot dengan fleksibility exercises secara teratur dapat membantu mengatasi kekakuan otot. Sebelum melakukan fleksibility exercises terlebih dahulu memeriksa kondisi kesehatan kepada petugas kesehatan (Cancer Council, 2016).

Pasien kanker yang menjalani perawatan harus aktif melakukan latihan pergerakan untuk menjaga dan meningkatkan kemampuan Activity Daily Living's (ADL's) sesuai dengan kemampuan tubuh terhadap aktivitas fisik tersebut. Latihan fisik juga dilakukan sesuai anjuran petugas kesehatan dan terporgram selama masa pengobatan atau perawatan. Sebelum melakukan latihan pergerakan pasien harus berkonsultasi kepada ahli terapi fisik untuk membantu latihan pergerakan yang aman, efektif dan menyenangkan bagi pasien (American Cancer Society, 2014). Menurut Canadian Cancer Society (2018) kemampuan aktivitas fisik setiap orang berbeda, namun tujuan dari latihan fisik tersebut adalah untuk menjaga daya tahan tubuh, kekuatan dan fleksibilitas sendi dan otot setiap individu.

Lakukan latihan fisik pada saat energi didalam tubuh cukup serta merasa aman dan nyaman saat melakukan aktivitas fisik. Menurut Cancer Council tips untuk melakukan latihan fleksibility exercises adalah lakukan pemanasan otot terlebih dahulu, pertahankan postur yang baik, meregangkan perlahan, jangan terpental, tetap bernapas dengan normal, jangan menahan napas dan ketahui keterbatasan anda dalam melakukan aktivitas fisik serta tidak merasakan sakit pada saat latihan berlangsung. Adapun kiat yang perlu diperhatikan pasien kanker selama melakukan aktivitas fisik dengan fleksibility exercises adalah sebagai berikut:

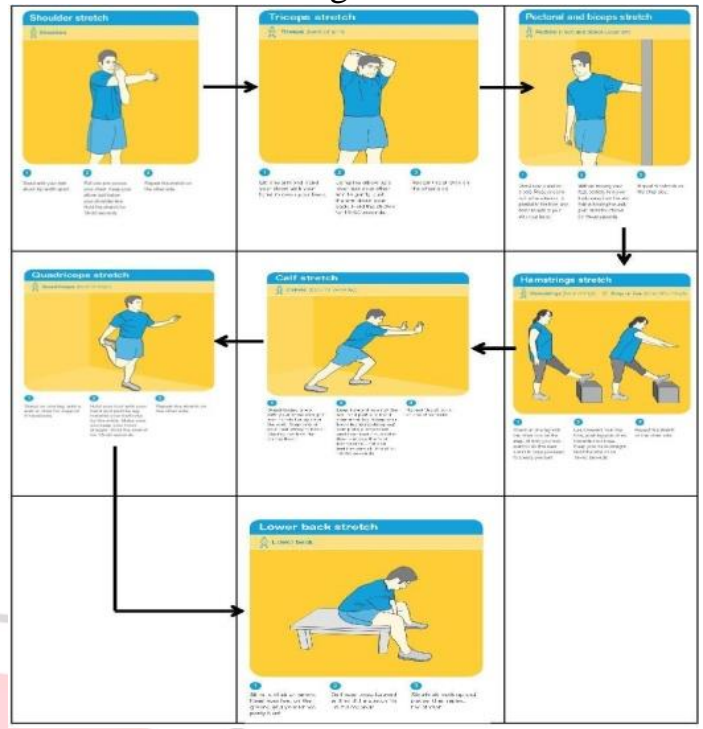

Gambar 1. Alur Kerja Intervensi Latihan Fisik Fleksibility Exercises

Sumber : Cancer Council (2016)

Activity Daily Living's (ADL's) merupakan kebutuhan fisiologis dan kebutuhan yang paling dasar untuk dipenuhi sehingga dapat mempertahankan kehidupan. Kebutuhan Activity Daily Living's (ADL's) terdiri dari mandi, berpakaian, makan, berhias, kebersihan diri, mengatur keuangan, memakai telepon, menggunakan kursi roda, pengobatan dan toileting (Moorhead et al, 2013). Pasien kanker mengalami keluhan terhadap kemampuan melakukan Activity Daily Living's (ADL's) dirumah yaitu sebanyak $65 \%$ responden mengatakan mengalami gangguan aktivitas perawatan diri, 25\% mengalami gangguan rekreasi dan 19\% mengalami gangguan terhadap pekerjaan yang menghasilkan keuangan.

Hasil penelitian Silaen (2018), pengaruh pemberian konseling dengan tingkat kecemasan pada pasien yang menjalani hemodialisis di Rumah Sakit Kota Medan, dimana penelitian didapatkan pengaruh pemberian konseling pada pasien hemodialisis dengan tingkat kecemasan, diperoleh bahwa nilai $\mathrm{p}$ value 0.00 . Diharapkan kepada perawat untuk memberikan edukasi dan konseling kepada pasien hemodialisis yang sedang menjalani hemodialisis agar pasien merasa nyaman dan tidak cemas dan dapat menjaga 
berat badan pasien serta dapat melakukan perawatan diri sendiri.

Kemampuan sesorang dalam melakukan Activity Daily Living's (ADL's) dapat dinilai berdasarkan tingkat ketergantungan individu dalam melakukan Activity Daily Living's ( $A D L$ 's) tersebut dan dikategorikan dengan kriteria ketergantungan total, membutuhkan pertolongan dari orang lain serta alat bantu, membutuhkan pertolongan orang lain sebagai pengawasan dan motivasi, membutuhkan peralatan atau alat bantu dan mandiri (Ahem, R.N et al, 2014).

Alat ukur yang digunakan untuk mengukur kemampuan individu melakukan Activity Daily Living's (ADL's) yaitu dengan Lawton and Brody Instrumental Activity yang terdiri dari 8 item penilaian diantaranya; kemampuan untuk mengggunakan telepon, shoping atau berbelanja, mempersiapkan makanan, menjaga kebersihan rumah, mencucui pakaian, cara transportasi, tanggung jawab terhadap pengobatan dan kemampuan terhadap mengatur keuangan. Skor penilaian kemampuan Activity Daily Living's (ADL's) ini dikategorikan menjadi dua bagian yaitu kemampuan aktivitas sehari-hari rendah (ketergantungan) dan kemampuan aktivitas sehari-hari tinggi (mandiri). Tingkat ketergantungan sehari-hari pasien dibagi dalam tiga kategori yaitu ketergantungan minimal (ringan), ketergantungan parsial (sedang) dan ketergantungan total (berat), (Graf C, 2007).

\section{METODE}

Jenis Penelitian ini adalah kuantitatif dengan design quasy experiment untuk menguji hubungan sebab akibat atau mencari pengaruh dari suatu intervensi terhadap responden tanpa adanya randomisasi penetuan subjek penelitian. Rancangan peneltian yang digunakan adalah one group pre-post test design, yaitu dengan memberikan perlakuan fleksibility exercises terhadap kelompok intervensi (Wood et al, 2014).

Penelitian ini dilakukan di Murni Teguh Memorial Hospital dengan alasan Rumah Sakit ini adalah Rumah Sakit Tipe B dengan akreditasi Paripurna yang memiliki keunggulan dibidang onkologi atau kanker.
Adapun waktu penelitian ini dilaksanakan bulan April sampai dengan Agustus 2019.

Populasi penelitian ini adalah seluruh pasien kanker di Murni Teguh Memorial Hospital dengan tekhnik pengambilan sampel accidental sampling serta disesuaikan dengan kriteria sampel yang ditentukan. Adapun kriteria inklusi pada penelitian ini adalah pasien yang menjalani kemoterapi, tidak memiliki luka akibat kanker, tidak mengalami anemia, tidak mengalami fraktur, berjenis kelamin perempuan, kooperatif dan memiliki rekomendasi dari dokter untuk melakukan latihan fisik dengan flexibility exercises yang berjumlah 30 orang.

\section{HASIL}

\section{Analisa Univariat}

\section{Karakteristik Responden}

Tabel 1. Distribusi Frekuensi Karakteristik Responden Berdasarkan Umur, Pendidikan dan Status Perkawinan di Unit Kemoterapi Murni Teguh Memorial Hospital (n=30)

\begin{tabular}{|c|c|c|c|}
\hline \multirow{2}{*}{ No } & \multirow{2}{*}{ Karakteristik } & \multicolumn{2}{|c|}{ Responden } \\
\hline & & $\mathrm{F}$ & $\%$ \\
\hline 1 & Umur & & \\
\hline & 26-35 tahun & 4 & 13.3 \\
\hline & 36-45 tahun & 9 & 30.0 \\
\hline & 46-55 tahun & 11 & 37.7 \\
\hline & 56-65 tahun & 6 & 20.0 \\
\hline 2 & Pendidikan & & \\
\hline & SD & 0 & 00.0 \\
\hline & SMP & 5 & 16.7 \\
\hline 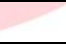 & SMA & 15 & 50.0 \\
\hline 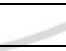 & $\mathrm{PT}$ & 10 & 33.3 \\
\hline 3 & $\begin{array}{l}\text { Status } \\
\text { Perkawinan }\end{array}$ & & \\
\hline & Kawin & 26 & 86.7 \\
\hline & Tidak kawin & 4 & 13.3 \\
\hline
\end{tabular}

Berdasarkan hasil uji statistik univariat terhadap karaktersitik responden dapat dilihat pada table diatas bahwa dari30 responden mayoritas umur responden 46-55 tahun11 orang $(37.7 \%)$, pendidikan SMA 15 orang $(50,0 \%)$, kemudian status perkawinan mayoritas kawin 26 orang (86.7\%).

Tabel 2. Distribusi Gambaran Kemampuan Activity Daily Living's (ADL's) Sebelum dan Sesudah Dilakukan Latihan fisik dengan Flexibility Exercises 


\begin{tabular}{llccl}
\hline \multicolumn{1}{c}{ Hari } & Median & Modus & Min-Maks \\
\hline $\mathbf{1}$ & $\begin{array}{l}\text { Sebelum dilakukan } \\
\text { latihan fisik dengan } \\
\text { Flexibility Exercises }\end{array}$ & 20 & 21 & $10-23$ \\
\hline $\mathbf{2}$ & $\begin{array}{l}\text { Sesudah dilakukan } \\
\text { latihan fisik dengan } \\
\text { Flexibility Exercises }\end{array}$ & 23 & 24 & $13-25$ \\
\hline
\end{tabular}

Tabel diatas menunjukkan bahwa

Kemampuan Activity Daily Living's (ADL's) sebelum dilakukan Latihan fisik dengan Flexibility Exercises yaitu median 20, modus 21, nilai terendah 10 dan nilai tertinggi 23. Kemampuan Activity Daily Living's (ADL's) sesudah dilakukan latihan fisik dengan Flexibility Exercises yaitu median 23, modus 24, nilai terendah 13 dan nilai tertingi 25 .

\section{Analisa Bivariat}

Tabel 3. Perbedaan Kemampuan Activity Daily Living's (ADL's) Sebelum dan Sesudah Latihan Fisik dengan Flexibility Exercises

\begin{tabular}{lllrrrr}
\hline & & & $\mathrm{N}$ & MeanRank & Sum of Rank & $\mathrm{p}$-Value \\
\cline { 3 - 5 } & & & & .00 & 0.00 \\
\hline Kemampuan & ADL`s & Negative Ranks & 0 & 0,00 & \\
\hline Pre-Kemampuan & Positive Ranks & 30 & 15,50 & 465.0 & \\
ADL`s Post & Ties & 0 & & & \\
& Total & 30 & & & \\
\hline
\end{tabular}

Tabel diatas menunjukkan negatif ranks atau selisih (negatif) antara hasil kemampuan Activity Daily Living's (ADL's) Sebelum dan Sesudah dilakukan latihan fisik dengan Flexibility Exercises adalah 0, baik itu pada nilai N, Mean Rank, maupun Sum of Rank. Nilai 0 ini menunjukkan tidak adanya penurunan kemampuan dari sebelum kesesudah dilakukan latihan fisik dengan Flexibility Exercises.

Kemudian pada hasil Positif Rank satu selisih (positif) antara hasil kemampuan Activity Daily Living's (ADL's) Sebelum dan Sesudah dilakukan latihan fisik dengan Flexibility Exercises menunjukkan bahwa 30 responden mengalami peningkatan kemampuan Activity Daily Living's (ADL's) dari nilai Sebelum kenilai Sesudah dilakukan latihan fisik dengan Flexibility Exercises Mean Rank atau rata-rata peningkatan tersebut adalah sebesar 15,50, sedangkan jumlah Sum of Ranks adalah sebesar 465.0. Nilai Ties adalah 0, sehingga dapat dikatakan bahwa tidak ada hasil kemampuan Activity Daily Living's ( $A D L$ 's) yang sama antara sebelum dan sesudah dilakukan latihan fisik dengan Flexibility Exercises.

Berdasarkan tabel diatas juga diketahui nilai p-Value 0,00 maka terdapat perbedaan kemampuan Activity Daily Living's (ADL's) yang signifikan antara sebelum dan sesudah dilakukan latihan fisik dengan Flexibility Exercises, sehingga dapat disimpulkan bahwa ada pengaruh latihan fisik dengan Flexibility Exercises terhadap kemampuan Activity Daily Living's ( $A D L$ 's) pada pasien kanker di Murni Teguh Memorial Hospital.

\section{PEMBAHASAN}

Dari hasil penelitian yang dilakukan pada pasien kanker di Murni Teguh Memorial Hospital pada 30 responden didapatkan hasil bahwa kemampuan Activity Daily Living's $(A D L$ 's) sebelum dan sesudah dilakukan latihan fisik dengan Flexibility Exercise ratarata mengalami peningkatan, artinya responden dapat melakukan Activity Daily Living's (ADL's) setelah diberikan latihan fisik dengan Flexibility Exercise. Selama ini responden belum memperoleh informasi yang relevan terkait dengan latihan fisik dengan Flexibility Exercise sehingga sering mengalami kelelahan, kekakuan pada otot dan sendi-sendi yang dapat mengganggu aktivitas sehari-hari responden. Oleh karena itu, peneliti memberika nlatihan fisik dengan Flexibility Exercise secara terus-menerus kepada responden selama 30 kali pertemuan dan memberikan informasi terkait gejala yang mungkin muncul akibat adanya kekakuan dan kelemahan pada otot dan sendi, jika gejala tersebut sering dialami dan tidak dilakukan latihan fisik dengan Flexibility Exercise maka akan dapat mempercepat atau memperberat kerusakan fungsi fisiologis tubuh lainnya. 
Penelitian terdahulu yang dilakukan oleh Tarihoran (2019) juga telah memberikan gambaran mengenai Shaker Exercise yang dilakukan secara rutin akan menguatkan otot dan mempercepat penyembuhan.

Berdasarkan uji statistic juga diperoleh nilai p-Value 0.00 Hal ini menunjukkan bahwa ada pengaruh latihan fisik dengan Flexibility Exercise terhadap kemampuan Activity Daily Living's ( $A D L$ 's) pada pasien kanker di Murni Teguh Memorial Hospital. Hasil penelitian ini juga sejalan dengan penelitian yang dilakukan oleh Kamariah (2018), yang menunjukkan adanya perbedaan dan penurunan tingkat fatigue pada penderita kanker serviks sebelum dan sesudah latihan fisik minimal, begitu juga dengan penelitian yang dilakukan oleh (Taukhid, 2017) terdapat penurunan skor fatigue yang bermakna antara sebelum dan sesudah melakukan kombinasi latihan aerobik dengan teknik relaksasi yoga.

\section{KESIMPULAN}

Bedasarkan hasil penelitian tentang pengaruh latihan fisik dengan Flexibility Exercises terhadap Kemampuan Activity Daily Living's $(A D L$ 's $)$ Pasien Kanker di MurniTeguh Memorial Hospital Tahun 2019 dapat ditarik kesimpulan bahwa latihan fisik dengan Flexibility Exercises yang diberikan selama sepuluh minggu dan sebanyak tiga kali pertemuan dalam satu minggu diperoleh $\mathrm{p}$ Value 0.00. Hal ini berarti ada pengaruh yang signifikan antara sebelum dan sesudah diberikan latihan fisik dengan Flexibility Exercises terhadap kemampuan Activity Daily Living's ( $A D L$ 's) pada pasien kanker.

Hasil penelitian Silaen (2019), diperoleh bahwa ada pengaruh yang signifikan antara pemberian konseling dengan tingkat kecemasan pada pasien pemasangan chemoport yang menjalani kemoterapi yang baru untuk mengatasi kecemasan sehingga dapat melakukan aktifitas mandiri tanpa bantuan orang lain.

\section{SARAN}

a. Bagi Institusi Pendidikan Kesehatan Hasil penelitian ini menunjukkan ada pengaruh latihan fisik dengan Flexibility
Exercises, untuk itu diharapkan latihan fisik dengan Flexibility Exercises dapat dijadikan sebagai salahs atu literature dalam upaya meningkatkan kemampuan Activity Daily Living's (ADL's) pada pasien kanker. Selain itu, dapat juga dikembangkan dalam kurikulum mata ajar KMB.

b. Bagi institusi pelayanan kesehatan

Hasil penelitian ini menunjukkan ada pengaruh latihan fisik dengan Flexibility Exercises jika dilakukan secara terus menerus dan terstruktur, untuk itu melalui bidang pendidikan dan latihan bekerja sama dengan bidang keperawatan perlu mengembangkan program pengembangan pelatihan perawat terkait latihan fisikd engan Flexibility Exercises agar dapat dihasilkan perawat yang berkompeten di bidang pendidikan kesehatan bagi pasien kanker.

c. Bagi Penelitian Selanjutnya

Bagi penelitian selanjutnya perlu dilakukan penelitian seperti ini kembali dengan jumlah sampel yang lebih banyak sehingga dapat memberikan power yang lebih tinggi lagi. Disamping itu, perlu juga dilakukan kombinasi dengan latihan fisik minimal lainnya untuk meminimalisir komplikasi yang mungkin terjadi akibat kelemahan, kekakuan otot dan sendi pada pasien kanker.

\section{DAFTAR PUSTAKA}

Ahern, R.N. \& Wilkinson, J.M. (2014). Buku Saku Diagnosa Keperawatan. Edisi 9. Jakarta: EGC.

American Cancer Society. (2014). Physical Activity And The Cancer Patient. URL: https://www.cancer.org/treatment/survivo rship-during-and aftertreatment/ staying - active/physical-activity-and-the-cancerpatient.html.Diaksespadatanggal 08 Mei2018.

Canadian Cancer Society. (2018). Physical Activity During Cancer Treatment. URL: http://www.cancer.ca/en/cancerinformation/cancer-journey/living-withcancer/physical- activity-during-cancertreatment/?region $=$ on .

Diaksespadatanggal 18 Agustus2018. 
Cancer Council. (2016). Execises For People Livingwith Cancer . Australia: Cancer Council Australia. Diakses pada tanggal 15 Agustus $2018 . \quad$ URL: https://www.cancerwa.asn.au/resources/2 016-06-08-Exercise-for-people-livingwith-cancer.pdf.

Don \& Dizon. (2017). Making A Diffrencein Cancer Care With You. (vol-37). Chicago: American Society of Clinical Oncology.

Graf, C. (2007). The Lawton Instrumental Activites Of Daily Living's (IADL) Scale. AJL. Volume 108 (4).

Hidayat, A.A. \& Uliyah, M. (2012). Buku Ajar Kebutuhan Dasar Manusia. Surabaya : Health Books Publishning.

International Agency for Research on Cancer. (2013). Latest World Cancer Statistics Global Cancer Burden Rises To 14.1 Milion New Cases In 2012: Market Increase In Breast Cancer Must Be Addressed. Diakses pada tanggal 03 Agustus $2018 . \quad$ URL: https://www.iarc.fr/en/mediacentre/pr/2013/pdfs/pr223_E.pdf.

Jacobsen L.L., hansen, DG., Waherens, EE., Cour, K., \& Soundergaard, J. (2015). Performance Of Activites Of Daily Living Among Hospitalized Cancer Patients. PubMed.gov. volume 22(2):13746. DOI:3109/11038128.2014.985253.

Kamariah, N. (2018). Pengaruh Latihan Fisik Minimal Terhadap Fatigue Pasien Kanker Serviks di RSUP Haji Adam Malik. Medan: Universitas Sumatera Utara $U R L$ :

http://repositori.usu.ac.id/handle/123456 789/4990

Min, H., Mobahi, H., irvin, K., Avramovic, S., \& Wojhtusiak, J. (2017). Predicting Activities Of Daily Living For Cancer Patient Using An Ontology-Guided Machine Learning Methodology. Journal of Biomedial semantics (2017). DOI:10.1186/s13326-017-0149-6.

Moorehad, S. Jhonson, M., Maas, M.L., \& Swanson, E. (2013). nursing outcome classification (NOC). Mosby: Elsevier.
Potter \& Perry. (2006). Buku Ajar Fundamentl Keperawatan. Jakarta: EGC.

Powers, S.K and jackson, M J. (2008). Exercise-Induced Oxidative Stress: Cellular Mechanisms And Impact On Muscle Force Production. Phsiol Rev 88:1243-1276.

Silaen, Harsudianto. (2018). Pengaruh Pemberian Konseling dengan Tingkat Kecemasan pada Pasien yang Menjalani Hemodialisis di Rumah Sakit Kota Medan. Jurnal Keperawatan Ilmiah Imelda. Vol. 4, No. 1, Februari 2018, ISSN 2597-7172.

Silaen, Harsudianto. (2019). Pengaruh Pemberian Konseling dengan Tingkat Kecemasan pada Pasien Pemasangan Chemoport yang Menjalani Kemoterapi di Rumah Sakit Kota Medan. Jurnal Keperawatan Priority. Vol. 2, No. 1, Januari 2019, ISSN 2614-4719

Tarihoran, Yusrial. (2019). Pengaruh Shaker Exercise Terhadap Kemampuan Menelan Pada Pasien Stoke Dengan Disfagia Di Rumah Sakit Kota Medan. Indonesian Trust Health Journal. Volume 1- No. 2 April 2019.

Taukhid, M. (2017). Manajemen Fatigue Melalui Kombinasi Aerobik dengan Relaksasi Yoga pada Penderita Kanker Payudara dalam Program Kemoterapi. Jurnal Ilmu Keseshatan. Vol. 5 No. 2, Mei 2017.

Wood, J.L.\& Heber, J. (2014). Nursing Research Methodes And Critical Appraisal For Evidence-Based Practice. $8^{\text {th }}$ Edition. St.Louis: Mosby Elsevier

Wiharja, A. (2016). The New Perspective Of Exercis As A Breast Cancer Therapy. Journal of Medicine and Health. Vol.1 No.3 Februari 2016.

Zhao, G., Li, Li, Li, J., Lina, S., \& Balluz. (2012). Physical Activity, Phychological Distress, And Receipt Of Mental Healhcare Services Among Cancer Survivor. J Cancer Surviv. (7):131-139. DOI: 10.1007/s11764-012-0254-6. 